\title{
PENGARUH KUALITAS PRODUK TERHADAP KEPUASAN KONSUMEN MEMBELI KOSMETIK BB CREAM WARDAH DI KOTA PALU
}

\author{
Suci fidiah lestari \\ Maskuri sutomo \\ Farid \\ Program Studi Manajemen, Fakultas Ekonomi, Universitas Tadulako \\ Email: Sucifidiahlestari@gmail.com, maskuri.sutomo@yahoo.com, farid4567@yahoo.com
}

\begin{abstract}
Suci Fidiah Lestari. "The Effect of Product Quality on Consumer Satisfaction on Buying BB Cream Wardah Cosmetics in Palu City."Supervised by Maskuri Sutomo and Farid.

This study aims to determine the effect of product quality which consists of performance, features, reliability, suitability, serviceability, durability, aesthetics, perception of quality on customer satisfaction buying BB Cream Wardah cosmetics in Palu City. The type of research used is quantitative (shows the relationship between variables). The population in this study were all users and buyers of BB Cream Wardah in Palu City. The sampling technique in this study uses purposive sampling, with a total sample of 90 respondents. Retrieval of data using a questionnaire. The analytical method used is multiple linear regression analysis, $F$ test, and t test. The results showed that performance, features, reliability, suitability, serviceability, durability, aesthetics, perceived quality had a significant effect on consumers' satisfaction of buying BB Cream Wardah cosmetics in Palu City simultaneously or partially.
\end{abstract}

Keywords: Performance, Privileges, Reliability, Suitability, Capability.

\section{ABSTRAK}

Suci Fidiah Lestari. "Pengaruh Kualitas Produk Terhadap Kepuasan Konsumen Membeli Kosmetik BB Cream Wardah Di Kota Palu.'Dibimbing oleh Maskuri Sutomo dan Farid. Penelitian ini bertujuan untuk mengetahui pengaruh kualitas produk yang terdiri dari kinerja, keistimewaan, keandalan, kesesuaian, kemapuan melayani, daya tahan, estetika, persepsi terhadap kualitas terhadap kepuasan konsumen membeli kosmetik BB Cream Wardah di Kota Palu.Jenis penelitian yang digunakan adalah kuantitatif (menunjukan hubungan antar variabel).Populasi dalam penelitian ini adalah seluruh pengguna dan pembeli BB Cream Wardah di Kota Palu.Teknik pengambilan sampel dalam penelitian ini menggunakan purposive sampling, dengan jumlah sampel sebanyak 90 responden.Pengambilan data menggunakan kuesioner. Metode analisis yang digunakan analisis regresi linier berganda, uji F, dan uji t. Hasil penelitian menunjukan bahwa kinerja, keistimewaan, keandalan, kesesuaian, kemapuan melayani, daya tahan, estetika, kualitas yang dipersepsikan berpengaruh signifikan terhadap kepuasan konsumen membeli kosmetik BB Cream Wardah di Kota Palu secara simultan maupun parsial.

Kata Kunci: Kinerja, Keistimewaan, Keandalan, Kesesuaian, Kemapuan Melayani.

\section{PENDAHULUAN}

Persaingan antar pasar industri perawatan pribadi dan kosmetik semakin kompetitif. Hal ini terbukti dengan banyaknya jenis kosmetika beredar baik produksi dalam negeri maupun produksi luar negeri.Membanjirnya produk kosmetika di pasaran mempengaruhi sikap seseorang terhadap pembelian dan pemakaian barang.

Pertumbuhan konsumen, terutama konsumen kosmetik meningkat luar biasa. Ditengah-tengah persaingan yang begitu tajam akibat banyaknya merek pendatang baru. BB Cream Wardah yang sudah lama berada di Indonesia dengan segala keunggulannya, tetap mendominasi pasar dan sekaligus memenuhi kebutuhan wanita, dan ekonomis. Wardah ini memiliki dua jenis BB Cream diantaranya 
adalah BB Cream Wardah everyday danWardah Lightening BB Cream. Dua BB Cream wardah ini memiliki fungsi dan keunggulan tersendiri, Wardah Everyday BB Cream untuk kulit yang berminyak dan BB Cream Wardah lightening untuk kulit yang kering.

Salah satu penyebab meningkatnya penjualan BB Cream Wardah yaitu kualitas produk dengan beberapa keunggulan yang dimiliki.Selain itu harga yang diterapkan untuk dapat membeli produk BB Cream Wardah relatif murah dan sangat cocok disemua kalangan di Kota Palu, hanya dengan mengeluarkan uang sebesar Rp.35.000 kita sudah dapat membeli dan menggunakan BB Cream Wardah.Berdasarkan pada fenomena di atas dan masih belum banyak yang meneliti maka perlu adanya penelitian yang bertujuan untuk Pengaruh kualitas produk terhadap kepuasan konsumen membeli kosmetik BB Cream Wardah di Kota Palu. Adapun tujuan yang ingin dicapai dalam penelitian ini adalah:

1. Untuk mengertahui pengaruh variabel kualitas produk yang terdiri dari kinerja, kistimewaan, kesesuaian, keandalan, daya tahan, kualitas melayani,estetika, kualitas yang dipersepsikan secara simultan terhadap kepuasab konsumen membeli kosmetik BB Cream Wardah di Kota Palu.

2. Untuk mengetahui pengaruh variabel kualitas produk terdiri dari kinerja, kistimewaan, kesesuaian, keandalan, daya tahan, kualitas melayani,estetika, kualitas yang dipersepsikan secara parsial terhadap kepuasab konsumen membeli kosmetik BB Cream Wardah di Kota Palu.

\section{KAJIAN LITERATURE}

Tjiptono (2008:25) menyatakan Ada delapan dimensi kualitas produk yang dikembangkan dan dapat diganakan sebagai kerangka perencanaan strategis dan analisis. Dimensi-dimensi tersebut adalah:
a. Kinerja (Performance)
b. Keistimewaan Tambahan (Features)
c. Kehandalan (Reliability)
d. Kesesuaian (Conformance)
e. Daya Tahan (Durability)
f. Kemampuan pelayanan (Serviceability)
g. Estetika (Aestheties)
h. Kualitas yang dipersepsikan (Perceived quality)

Kotler dan Keller (2009: 138) menyatakan Kepuasan pelanggan (satisfaction) adalah ungkapan perasaan senang atau kecewa seseorang yang timbul setelah membandingkan kinerja yang diharapkan dengan kenyataan yang diperoleh. Aan (2017).Kualitas produk dan nilai pelanggan secara simultan berpengaruh signifikan terhadap loyalitas pelanggan 


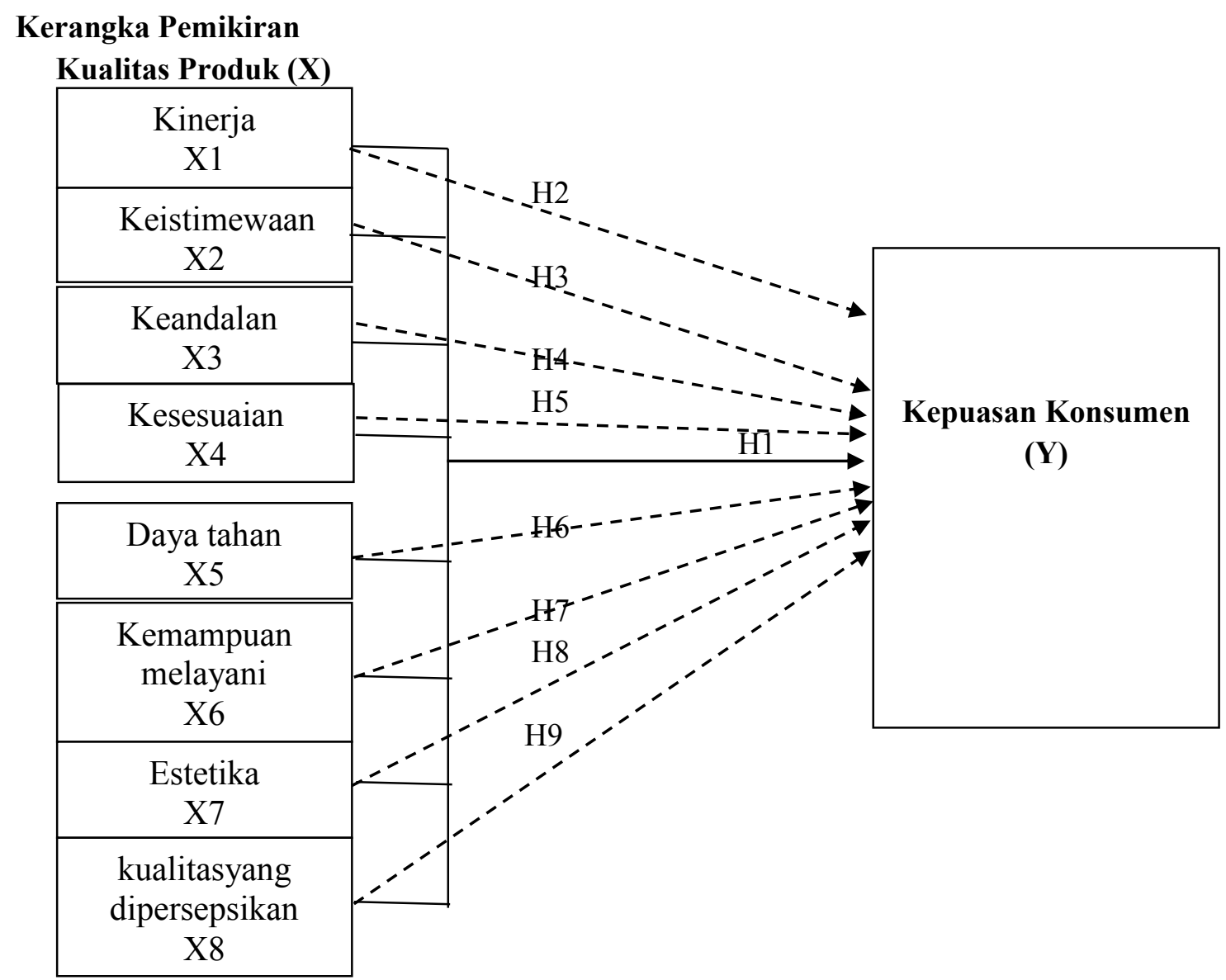

Sumber: Data Diolah 2017

\section{Gambar 1}

\section{Paradigma Konseptual Pemikiran}

\section{Hipotesis}

Hipotesis penelitian adalah dugaan sementara peneliti bahwa:

a. Kualitas produk yang terdiri dari Kinerja, Keistimewaan, Keandalan, Kesesuaian, Kemampuan melayani, Daya Tahan, Estetika, Kualitas yang dipersepsikan dan kepuasan konsumen secara simultan berpengaruh terhadap kepuasan konsumen membeli kosmetik BB Cream Wardah di Kota Palu

b. Kinerja berpengaruh positif dan signifikan terhadap kepuasan konsumen membeli kosmetik BB Cream Wardah di Kota Palu

c. Keistimewaan berpenggaruh positif dan signifikan terhadap kepuasan konsumen membeli kosmetik BB Cream Wardah di Kota Palu

d. Keandalan berpenggaruh positif dan signifikan terhadap kepuasan konsumen membeli kosmetik BB Cream Wardah di Kota Palu

e. Kesesuaian berpenggaruh positif dan signifikan terhadap kepuasan konsumen membeli kosmetik BB Cream Wardah di Kota Palu

f. Kemampuan melayani berpenggaruh positif dan signifikan terhadap kepuasan konsumen membeli kosmetik BB Cream Wardah di Kota Palu 
g. Daya Tahan berpenggaruh positif dan signifikan terhadap kepuasan konsumen membeli kosmetik BB Cream Wardah di Kota Palu

h. Estetika berpenggaruh positif dan signifikan terhadap kepuasan konsumen membeli kosmetik BB Cream Wardah di Kota Palu

i. Kualitas yang dipersepsikan berpenggaruh positif dan signifikan terhadap kepuasan konsumen membeli kosmetik BB Cream Wardah di Kota Palu.

\section{METODE PENELITIAN}

\section{Jenis Penelitian}

Penelitian ini merupakan jenis penelitian kausal dimana ditujukan untuk menganalisis hubungan sebab akibat antar variabel yaitu variabel-variabel Kualitas produk sebagai variabel bebas dan kepuasan konsumen sebagai variabel terikat. Menurut Sugiyono (2014:4), desain kausal adalah hubungan yang bersifat sebab akibat. Jadi, variabel independen (mempengaruhi) dan variabel dependen (dipengaruhi). Dimana penelitian kausal yaitu penelitian untuk menguji hubungan antara variabel yang dihipotesiskan.Hipotesis ini sendiri menggambarkan hubungan antara dua atau lebih variabel untuk mengetahui apakah variabel berasosiasi atau tidak dengan lainnya. Lokasi dalam penelitian ini adalah Toko Mutiara Kosmetik Palu yang bertempat di jalan Dokter Soetomo dan Fakultas Ekonomi.

Populasi pada penelitian adalah semua konsumen yang menggunakan produk BB Cream Wardah di Kota Palu.Adapun jumlah yang menggunakan produk BB Cream Wardah tidak diketahui secara pasti, dikarenakan tidak adanya data pendukung yang mencari jumlah secara pasti pengguna produk BB Cream Wardah di Kota Palu. Jumlah sampel yang akan diambil untuk mewakili populasi dalam penelitian ini sebanyak 90 sampel, jumlah sampel dalam penelitian ini merujuk pada teori Roscoe (dalam Sugiyono, 2014:91) adalah 10 kali dari jumlah variabel yang minimal diteliti (variabel independen + variabel dependen).

Jumlah variabel dalam penelitian ini adalah 9 yang terdiri dari variabel independen (kualitas produk) dan variabel dependen (kepuasan konsumen). Berdasarkan teori tersebut maka perhitungan sampel dalam penelitian ini ditetapkan sebanyak 90 responden. Karena populasi tidak diketahui maka Peneliti Menggunakan teknik penarikan sampel nonprobability sampling dengan teknik sampling insidental, Adapun metode analisis data dalam penelitian ini, yaitu:

1. Pengujian Instrumen

a. Uji validitas, sering digunakan untuk mengukur ketepatan suatu item dalam kuisioner, apakah item pada kuisioner tersebut sudah tepat dalam mengukur apa yang ingin diukur. Dalam rangka mengetahui uji validitas, dapat digunakan koefisien korelasi yang nilai $>0,3$ atau $3 \%$ (level of significance) menunjukkan bahwa pernyataan-pernyataan tersebut sudah sahih/valid, (Ghozali, 2011:45).

b. Uji Reliabilitas, berguna untuk menetapkan apakah instrumen, Uji reliabilitas untuk alternatif jawaban lebih dari dua menggunakan uji Cronbach's Alpha, yang nilainya akan dibandingkan dengan nilai koefisien reliabilitas minimal yang dapat diterima. Jika nilai nilai Cronbach's Alpha $>0,6$ maka instrumen penelitian reliabel (Ghozali, 2011:133).

2. Uji Asumsi Klasik

a. Uji Multikolinieritas,untuk mengetahui adanya gejala multikolinieritas dengan melihat nilai variance inflation factor (VIF). Nilai toleran yang lebih kecil dari 0,10 atau nilai VIF lebih besar dari 10, maka terjadi multikolinieritas Ghozali (2006:91).

b. Uji Heteroskedastitas, untuk mengetahui apakah variabel pengganggu (disturbance error) mempunyai varian konstan. Uji ini juga untuk menguji apakah dalam model regresi tidak terjadi 
ketidaksamaan variance dari residual satu pengamatan kepengamatan lainnya. Dasar pengambilan kepuasan, Jika tidak ada pola yang jelas, serta titik-titik menyebar diatas dan dibawah angka 0 pada sumbu Y, maka tida mengindikasikan masalah heterokedastitas, Ghozali (2006:105).

c. Uji Normalitas, Ghozali (2006:110) menyatakan deteksi normalitas dilakukan dengan melihat penyebaran data (titik) pada sumbu diagonal dari grafik. Dasar pengambilan kepuasan, Jika data tersebar di sekitar garis diagonal dan mengikuti arah garis diagonal maka model regresi memenuhi asumsi normalitas.

3. Regesi Linier Berganda

Metode yang digunakan dalam penelitian ini adalah dengan pendekatan statistik deskriptif melalui penggunaan alat analisis statistik Regresi Linier Berganda. Dalam hal ini, menggunakan bantuan komputer program SPSS Release 20.

\section{HASIL DAN PEMBAHASAN}

Berikut ini adalah hasil uji validitas dan reliabilitas atas item pertanyaan yang terdapat dalam kuesioner penelitian terhadap variabel Kualitas Produk (X), Kinerja (X1), Keistimewaan (X2), Kesesuaian (X3), Keandalan (X4), Daya tahan (X5), Kemapuan melayani (X6), Estetika (X7), Kualitas yang dipersepsikan (X8), Kepuasan konsumen (Y). Adapun hasilnya disajikan dalam tabel berikut:

Tabel 1

Validitas dan Reliabilitas Instrumen Penelitian

\begin{tabular}{|c|c|c|c|c|c|}
\hline Variabel & Item & $\begin{array}{c}\text { Total } \\
\text { Correlation }\end{array}$ & Ket & $\begin{array}{c}\text { Cronbach } \\
\text { Alpha }\end{array}$ & Ket \\
\hline \multirow{21}{*}{$\begin{array}{c}\text { Kualitas Produk } \\
\text { (X) }\end{array}$} & $\mathrm{X} 1.1$ & 0,605 & Valid & \multirow{3}{*}{0,686} & \multirow{3}{*}{ Reliabel } \\
\hline & $\mathrm{X} 1.2$ & 0,416 & Valid & & \\
\hline & $\mathrm{X} 1.3$ & 0,424 & Valid & & \\
\hline & $\mathrm{X} 2.1$ & 0,388 & Valid & \multirow{3}{*}{0,757} & \multirow{3}{*}{ Reliabel } \\
\hline & $\mathrm{X} 2.2$ & 0,886 & Valid & & \\
\hline & $\mathrm{X} 2.3$ & 0,620 & Valid & & \\
\hline & X3.1 & 0,525 & Valid & \multirow{3}{*}{0,764} & \multirow{3}{*}{ Reliabel } \\
\hline & $\mathrm{X} 3.2$ & 0,639 & Valid & & \\
\hline & X3.3 & 0,628 & Valid & & \\
\hline & $\mathrm{X} 4.1$ & 0.731 & Valid & \multirow{3}{*}{0,865} & \multirow{3}{*}{ Reliabel } \\
\hline & $\mathrm{X} 4.2$ & 0,735 & Valid & & \\
\hline & $\mathrm{X} 4.3$ & 0,763 & Valid & & \\
\hline & X5.1 & 0,444 & Valid & \multirow{3}{*}{0,618} & \multirow{3}{*}{ Reliabel } \\
\hline & $\mathrm{X} 5.2$ & 0,421 & Valid & & \\
\hline & X5.1 & 0,415 & Valid & & \\
\hline & X6.1 & 0,388 & Valid & \multirow{3}{*}{0,851} & \multirow{3}{*}{ Reliabel } \\
\hline & X6.2 & 0,688 & Valid & & \\
\hline & X6.3 & 0,351 & Valid & & \\
\hline & X7.1 & 0,652 & Valid & \multirow{3}{*}{0,851} & \multirow{3}{*}{ Reliabel } \\
\hline & $\mathrm{X} 7.2$ & 0,654 & Valid & & \\
\hline & $\mathrm{X} 7.3$ & 0,853 & Valid & & \\
\hline
\end{tabular}




\begin{tabular}{|c|c|c|c|c|c|}
\hline & $\mathrm{X} 8.1$ & 0,550 & Valid & \multirow{3}{*}{0,617} & \multirow{3}{*}{ Reliabel } \\
\hline & X8.2 & 0,359 & Valid & & \\
\hline & X8.3 & 0,383 & Valid & & \\
\hline \multirow{3}{*}{$\begin{array}{c}\text { Kepuasan } \\
\text { Konsumen (Y) }\end{array}$} & Y1 & 0,689 & Valid & \multirow{3}{*}{0,872} & \multirow{3}{*}{ Reliabel } \\
\hline & Y2 & 0,795 & Valid & & \\
\hline & Y3 & 0,759 & Valid & & \\
\hline
\end{tabular}

Sumber: Data diolah Tahun 2018

Berdasarkan hasil uji validitas dan reliabilitas diperoleh bahwa seluruh variabel memiliki koefisien Cronbach Alpha (a) lebih besar dari 0,6 sehingga berdasarkan syarat minimum reliabilitas lebih besar dari 0,6 maka seluruh variabel yang digunakan reliabel dan dapat digunakan dalam penelitian.

Sedangkan uji validitas terhadap seluruh variabel juga menunjukan nilai koefisien korelasi yang lebih besar dari 0,3 sehingga item pernyataan yang ada valid untuk digunakan.

Penelitian ini menggunakan analisis regresi linear berganda dengan tujuan untuk menguji pengaruh pengaruh pengetahuan kualitas produk terhadap kepuasan konsumen. Untuk lebih jelasnya hasil analisis regresi linear berganda dapat dilihat pada tabel berikut:

Tabel 2

Hasil Uji Analisis Regresi Linear Berganda

\begin{tabular}{|c|c|c|c|c|c|}
\hline \multicolumn{6}{|c|}{ Dependen Variabel $Y=$ Kepuasan Konsumen } \\
\hline \multirow[t]{2}{*}{ Variabel Independen } & \multicolumn{2}{|c|}{$\begin{array}{c}\text { Unstandardized } \\
\text { Coefficients }\end{array}$} & \multirow{2}{*}{$\begin{array}{c}\text { Standardized } \\
\text { Coefficients } \\
\text { Beta }\end{array}$} & \multirow[b]{2}{*}{$\mathbf{t}$} & \multirow{2}{*}{ Sig. } \\
\hline & B & Std.Error & & & \\
\hline (Constat) & -2.092 & 0,374 & & -5.590 & 0,000 \\
\hline Kinerja $(\mathrm{X} 1)$ & 0,241 & 0,070 & 0,218 & 3.466 & 0,001 \\
\hline Keistimewaan (X2) & 0,163 & 0,077 & 0,142 & 2.121 & 0,037 \\
\hline Keandalan (X3) & 0,148 & 0,048 & 0,156 & 3.077 & 0,003 \\
\hline Kesesuaian (X4) & 0,176 & 0,068 & 0,157 & 2.573 & 0,012 \\
\hline Daya Tahan (X5) & 0,168 & 0,067 & 0,170 & 2.519 & 0,014 \\
\hline Kemampuan melayani (X6) & 0,165 & 0,074 & 0,146 & 2.224 & 0,029 \\
\hline Estetika (X7) & 0,272 & 0,075 & 0,242 & 3.627 & 0,001 \\
\hline Persepsi terhadap kualitas (X8) & 0,170 & 0,068 & 0,158 & 2.483 & 0,015 \\
\hline $\begin{array}{ll}\text { Multiple R } & =0,896^{\mathrm{a}} \\
\text { Sig F }=0,000^{\mathrm{a}} & \\
\text { R Square } & =0,802\end{array}$ & & & & & \\
\hline
\end{tabular}

\section{Sumber: Data diolah Tahun 2018}

Berdasarkan tabel di atas, dapat di tulis dalam bentuk persamaan regresi linear berganda. Untuk lebih jelasnya bentuk persamaan tersebut dapat dilihat sebagai berikut:

$Y=-\mathbf{2 . 0 9 2}+0,241 X_{1}+0,163 X_{2}+0,148 X_{3}+0,176 X_{4}+0,168 X_{5}+0,165 X_{6}+0,272 X_{7}+0,170 X_{8}$

Berdasarkan penjabaran di atas menunjukkan bahwa, variabel independen yang dianalisis yaitu variabel Xmemberikan pengaruh positif terhadap variabel dependen (Y), yaitu kepuasan konsumen menggunakan BB Cream Wardah di Kota Palu. Untuk lebih jelasnya penjelasan bentuk persamaan tersebut dapat dilihat berikut ini:

1. Nilai Konstanta sebesar -2.092, artinya jika variabel Kualitas Produk $(\mathrm{X} 1, \mathrm{X} 2, \mathrm{X} 3, \mathrm{X} 4, \mathrm{X} 5, \mathrm{X} 6, \mathrm{X} 7, \mathrm{X} 8)$ bernilai 0, maka variabel dependen (kepuasan konsumen 
membeli BB Cream Wardah di Kota Palu) nilainya sebesar -2.092. setiap ada kenaikan pada variabel independen sebesar satu satuan maka akan meningkatkan variabel dependen sebesar nilai koefisiensi beta masing-masing variabel independen dikalikan dengan besarnya kenaikan yang terjadi.

2. Koefisien regresi dimensi dimensi Kualitas Produk $\left(\mathrm{X}_{1}\right)$ sebesar 0,241, $\left(\mathrm{X}_{2)}\right.$ sebesar 0,163, $\left(\mathrm{X}_{3)}\right.$ sebesar 0,148, $\left(\mathrm{X}_{4)}\right.$ sebesar 0,176, $\left(\mathrm{X}_{5)}\right.$ sebesar 0,168, $\left(\mathrm{X}_{6}\right)$ sebesar 0,165, $\left(\mathrm{X}_{7}\right)$ sebesar $0,272,\left(\mathrm{X}_{8)}\right.$ sebesar 0,068 artinya bahwa pengaruh variabel Kualitas produk terhadap kepuasan konsumen menggunakan BB Cream Wardah di Kota Palu adalah bersifat positif dan jika skor variabel Kualitas produk meningkat maka kepuasan konsumen menggunakan BB Cream Wardah dikota palu juga akan meningkat.

\section{Hasil Pengujian Hipotesis}

Tahap selanjutnya adalah menguji signifikan hubungan atau uji $\mathrm{F}$ antar variabel penelitian yaitu kinerja (X1), keistimewaan (X2), kesesuaian (X3), keandalan (X4), daya tahan (X5), kemapuan melayani (X6), estetika (X7), kualitas yang dipersepsikan (X8), terhadap kepuasan konsumen (Y).

Berdasarkan tabel 2, diperoleh angka signifikan F sebesar 0,000. Angka $0,000<0,05$ hal ini berarti terdapat pengeruh secara simultan pada variabel kualitas produk yang tediri dari kinerja, keistimewaan, kesesuaia, keandalan, daya tahan, kemapuan melayani, estetika, kualitas yang dipersepsikan terhadap kepuasan kosumen BB Cream Wardah di Kota Palu dengan besar pengaruh $80,2 \%$. Oleh karna itu hipotesis diterima.

\section{Hasil Pengujian Hipotesis Secara Parsial (Uji t)}

Pengujian hipotesis secara parsial adalah untuk mengetahui apakah variabel kinerja, keistimewaan, kesesuaian, keandalan, daya tahan, kemapuan melayani, estetika, kualitas yang dipersepsikan secara parsial berpengaruh secara positif dan signifikan terhadap kepuasan konsumen BB Cream Wardah di Kota Palu. Adapun hasil pengujian secara parsial untuk setiap variabel independen terhadap variabel dependen dapat dilihat dari penjelsan berikut:

\section{Variabel Kinerja}

Berdasarkan tabel 2, hasil pengujian SPSS diperoleh hasil angka signifikan t sebesar 0,000 . Angka $0,000<0,05 \mathrm{Hal}$ ini berarti terdapat pengaruh variabel kinerja terhadap kepuasan konsumen BB Cream Wardah di Kota Palu dengan besar pengaruh 0,241 atau 24,1 $\%$. Oleh karna itu hipotesis diterima.

2. Variabel Keistimewaan

Berdasarkan tabel 2, hasil pengujian SPSS diperoleh hasil angka signifikan $\mathrm{t}$ sebesar 0,000 . Angka $0,000<0,05 \mathrm{Hal}$ ini berarti terdapat pengaruh variabel kinerja terhadap kepuasan konsumen BB Cream Wardah di Kota Palu dengan besar pengaruh 0,163 atau 16,3 $\%$. Oleh karna itu hipotesis diterima.

3. Variabel Kesesuaian

Berdasarkan tabel 2, hasil pengujian SPSS diperoleh hasil angka signifikan t sebesar 0,000 . Angka $0,000<0,05$ Hal ini berarti terdapat pengaruh variabel kinerja terhadap kepuasan konsumen BB Cream Wardah di Kota Palu dengan besar pengaruh 0,148 atau 14,8 $\%$. Oleh karna itu hipotesis diterima.

4. Variabel Keandalan

Berdasarkan tabel 2, hasil pengujian SPSS diperoleh hasil angka signifikan $\mathrm{t}$ sebesar 0,000 . Angka $0,000<0,05 \mathrm{Hal}$ ini berarti terdapat pengaruh variabel kinerja terhadap 
kepuasan konsumen BB Cream Wardah di Kota Palu dengan besar pengaruh 0,176 atau 17,6 $\%$. Oleh karna itu hipotesis diterima.

5. Variabel Daya tahan

Berdasarkan tabel 2, hasil pengujian SPSS diperoleh hasil angka signifikan $\mathrm{t}$ sebesar 0,000 . Angka $0,000<0,05 \mathrm{Hal}$ ini berarti terdapat pengaruh variabel kinerja terhadap kepuasan konsumen BB Cream Wardah di Kota Palu dengan besar pengaruh 0,168 atau 16,8 $\%$. Oleh karna itu hipotesis diterima.

6. Variabel Kemampuan melayani

Berdasarkan tabel 2, hasil pengujian SPSS diperoleh hasil angka signifikan t sebesar 0,000 . Angka $0,000<0,05 \mathrm{Hal}$ ini berarti terdapat pengaruh variabel kinerja terhadap kepuasan konsumen BB Cream Wardah di Kota Palu dengan besar pengaruh 0,165 atau 16,5 $\%$. Oleh karna itu hipotesis diterima.

7. Variabel Estetika

Berdasarkan tabel 2, hasil pengujian SPSS diperoleh hasil angka signifikan t sebesar 0,000 . Angka $0,000<0,05 \mathrm{Hal}$ ini berarti terdapat pengaruh variabel kinerja terhadap kepuasan konsumen BB Cream Wardah di Kota Palu dengan besar pengaruh 0,272 atau 27,2 $\%$. Oleh karna itu hipotesis diterima.

8. Variabel Kualitas yang dipersepsikan

Berdasarkan tabel 2, hasil pengujian SPSS diperoleh hasil angka signifikan $t$ sebesar 0,000 . Angka $0,000<0,05 \mathrm{Hal}$ ini berarti terdapat pengaruh variabel kinerja terhadap kepuasan konsumen BB Cream Wardah di Kota Palu dengan besar pengaruh 0,170 atau 17,0 $\%$. Oleh karna itu hipotesis diterima.

\section{Pembahasan atau Hasil Analisis}

Berdasarkan hasil pengujian serta analisis yang telah dilakukan pada penelitian ini membuktikan bahwa kualitas produk secara simultan berpengaruh signifikan terhadap kepuasan konsumen membeli BB Cream Wardah di Kota Palu. Diketahui dari nilai pengaruh, bisa dijelaskan bahwa pengaruh secara simultan (Kualitas Produk) terhadap kepuasan konsumen BB Cream Wardah adalah sebesar 0,802 $(80,2 \%)$, artinya kualitas produk mampu memberikan kontribusi terhadap pengeruh kepuasan konsumen dengan kemapuan sebesar 80,2 \%, dan artinya hanya sebesar 19,8 \% kepuasan konsumen yang dipengaruhi oleh variabel salain kualitas produk.

\section{Kinerja}

Hasil pengujian hipotesis penelitian, ditemukan bahwa kinerja berpengaruh terhadap kepuasan konsumen membeli kosmetik BB Cream Wardah di Kota Palu.kinerja adalah karakteristik utama dari suatu produk. Hasil penelitian sejalan dengan penelitian Mulyono (2007) bahwa kinerja berpengaruh positif dan signifikan terhadap kepuasan konsumen.

Penelitian yang dilakukan pada BB Cream Wardah, pada kinerja dimana kandungan BB Cream Wardah aman bagi kulit merupakan indikator yang dominan dipilih oleh reponden. Dikarnakan sudah terbukti kulit konsumen sejak pemakaian pertama pada produk tersebut tidak menimbulkan tandatanda alergi atatupun iritasi pada kulit.Hal ini mengartikan bahwa secara umum responden mengakui bahwa kinerja yang diberikan perusahaan BB Cream Wardah cukup berkualitas. menandakan bahwa kinerja yang diberikan terbukti cukup baik. hasil wawancara beberapa konsumen bahwa produk BB Cream Wardah aman bagi kulit mereka sehingga mereka puas dengan kinerja perusahaan tersebut.

\section{Keistimewaan}


Hasil pengujian hipotesis penelitian, ditemukan bahwa keistimewaan berpengaruh terhadap kepuasan konsumen membeli kosmetik BB Cream Wardah di Kota Palu.Hasil penelitian sejalan dengan penelitian Haryanto (2013) bahwa keistimewaan berpengaruh positif dan signifikan terhadap kepuasan konsumen.

Penelitian yang dilakukan pada BB Cream Wardah, pada keistimewaan memberikan hasil yang memuaskan saat diaplikasikan merupakan indikator yang dominan dipilih oleh reponden.Karna hasil dari pengaplikasian BB Cream Wardah membuat kulit wajah konsumen menjadi lebih cerah. Hal ini mengartikan bahwa secara umum responden mengakui bahwa keistimewaan yang diberikan perusahaan BB Cream Wardah sangat bagus.

\section{Keandalan}

Hasil pengujian hipotesis penelitian, ditemukan bahwa keandalan berpengaruh terhadap kepuasan konsumen membeli kosmetik BB Cream Wardah di Kota Palu.Hasil penelitian sejalan dengan penelitian Lenzun, et al (2014) bahwa keandalan berpengaruh positif dan signifikan terhadap kepuasan konsumen.

Penelitian yang dilakukan pada BB Cream Wardah, pada keandalan dimana Produk tetap baik digunakan saat mendekati tanggal kedaluarsa adalah indikator yang dominan dipilih oleh reponden. Hal ini mengartikan bahwa secara umum responden mengakui bahwa keandalan yang diberikan perusahaan BB Cream Wardah sangat baik. Hal ini menandakan bahwa keandalan dari produk ini membuktikan kualitas yang baik. Karna konsumen menggunakan produk ini saat mendekati tanggal kedaluarsa kulit konsumen tetap aman dan tidak menimbulkan dampak apapun pada kulit mereka. hasil wawancara beberapa konsumen bahwa produk BB Cream Wardah ini sangat berkualitas sehimgga mereka puas dengan perusahaan tersebut.

\section{Kesesuaian}

Hasil pengujian hipotesis penelitian, ditemukan bahwa kesesuaian berpengaruh terhadap kepuasan konsumen membeli kosmetik BB Cream Wardah di Kota Palu.Hasil penelitian sejalan dengan penelitian Mulyono (2007) bahwa kesesuaian berpengaruh positif dan signifikan terhadap kepuasan konsumen.

Penelitian yang dilakukan pada BB CreamWardah pada kesesuaian dimana produk memiliki uji laboratorium yang diakui adalah indikator yang dominan dipilih oleh reponden dikarnakan persepsi responden untuk semua jenis kulit kosmetik itu telah diuji terlebih dahulu sebelum dipasrkan pada konsumen. Hal ini mengartikan bahwa secara umum responden mengakui bahwa kesesuaian yang diberikan perusahaan BB Cream Wardah sangat baik.

\section{Daya tahan}

Hasil pengujian hipotesis penelitian, ditemukan bahwa daya tahan berpengaruh terhadap kepuasan konsumen membeli kosmetik BB Cream Wardah di Kota Palu. Hasil penelitian sejalan dengan penelitian Haryanto (2013) bahwa daya tahan berpengaruh positif dan signifikan terhadap kepuasan konsumen.

Penelitian yang dilakukan pada BB Cream Wardah pada Daya tahan dimana tidak mudah luntur saat diaplikasikan ke wajah merupakan indikator yang dominan dipilih oleh reponden, meskipun produk ini terpapar sinar matahari yang cukup lama namun daya ketahanan produk ini tetap baik dan tahan lama saat digunakan berjam-jam. Hal ini mengartikan bahwa secara umum responden mengakui bahwa Daya tahan yang diberikan perusahaan BB Cream Wardah sangat baik, Hal ini menandakan bahwa daya tahan dari produk ini sangat baik.hasil wawancara beberapa konsumen bahwa produk BB Cream Wardah ini sangat menyukai produk ini sehimgga mereka puas dengan perusahaan tersebut. 


\section{Kemampuan melayani}

Hasil pengujian hipotesis penelitian, ditemukan bahwa kemampuan melayani berpengaruh terhadap kepuasan konsumen membeli kosmetik BB Cream Wardah di Kota Palu. Hasil penelitian sejalan dengan penelitian Lenzun, et al (2014) bahwa kemampuan melayani berpengaruh positif dan signifikan terhadap kepuasan konsumen.

Penelitian yang dilakukan pada BB Cream Wardah pada kemampuan melayani dimana cepat tanggap dalam menjawab pertanyaan konsumen seputar produk indikator yang dominan dipilih oleh reponden.Hal ini dikarnakan perusahaan wardah memiliki kriteria tersendiri saat merekrut karyawan yang dapat melayani konsumen dengan baik yaitu salah satunya mempunyai kemapuan cepat dan tanggap perihal pertanyaan konsumen tentang produk BB Cream Wadah.Hal ini mengartikan bahwa secara umum responden mengakui bahwa kemapuan melayani konsumen yang juga membuat konsumen untuk terus membeli produk in karna mereka melayani dengan baik dan sopan. Hal ini menandakan bahwa kemampuan melayani yang juga membuat konsumen untuk terus membeli produk ini dikarnakan dilayani dengan baik dan sopan.

\section{Estetika}

Hasil pengujian hipotesis penelitian, ditemukan bahwa estetika berpengaruh terhadap kepuasan konsumen membeli kosmetik BB Cream Wardah di Kota Palu.Hasil penelitian sejalan dengan penelitian Haryanto (2013) bahwa estetika berpengaruh positif dan signifikan terhadap kepuasan konsumen.

Penelitian yang dilakukan pada BB Cream Wardah pada indikator estetika dimana memiliki 2 jenis warna natural dan light adalah indikator yang dominan dipilih oleh reponden. Hal ini dikarnakan bahwa konsumen menyukai produk yang memiliki beberapa pilihan warna dan wardah menjadi salah satu produk yang memiliki varian warna. Hal ini mengartikan bahwa secara umum responden mengakui bahwa estetika yang diberikan perusahaan BB Cream Wardah sangat unggul.

\section{Kualitas yang dipersepsikan}

Hasil pengujian hipotesis penelitian, ditemukan bahwa kualitas yang dipersepsikan berpengaruh terhadap kepuasan konsumen membeli kosmetik BB Cream Wardah di Kota Palu.Hasil penelitian sejalan dengan penelitian Mulyono (2007) bahwa kualitas yang dipersepsikan berpengaruh positif dan signifikan terhadap kepuasan konsumen.

Penelitian yang dilakukan pada BB Cream Wardah pada kualitas yang dipersepsikan dimana brand kosmetik yang sudah banyak di kenal orang merupakan indikator yang dominan dipilih oleh reponden.karna kualitas produk Wardah yang baik menyebabkan promosi mulut ke mulut yang dilakukan konsumen terbukti efektif sehingga produk banyak di kenal dan disukai dikalangan wanita. Hal ini mengartikan bahwa secara umum responden mengakui bahwa kualitas yang dipersepsikan yang diberikan perusahaan BB Cream Wardah cukup membuat konsumen yakin akan kualitas produk BB Cream Wardah.

\section{PENUTUP}

\section{Kesimpulan}

Berdasarkan hasil penelitian yang telah dijabarkan, maka diperoleh kesimpulan mengenai pengaruh kualitas produk terhadap kepuasan konsumen membeli BB Cream Wardah di Kota Palu sebagai berikut. 
1. Kualitas produk secara simultan berpengaruh signifikan terhadap kepuasan konsumen membeli BB Cream Wardah di Kota Palu.

2. Kinerja berpengaruh signifikan terhadap kepuasan konsumen membeli BB Cream Wardah di Kota Palu.

3. Keistimewaan berpengaruh signifikan terhadap kepuasan konsumen membeli BB Cream Wardah di Kota Palu.

4. Keandalan berpengaruh signifikan terhadap kepuasan konsumen membeli BB Cream Wardah di Kota Palu.

5. Kesesuaian berpengaruh signifikan terhadap kepuasan konsumen membeli BB Cream Wardah di Kota Palu.

6. Kemampuan melayani berpengaruh signifikan terhadap kepuasan konsumen membeli BB Cream Wardah di Kota Palu.

7. Daya tahan berpengaruh signifikan terhadap kepuasan konsumen membeli BB Cream Wardah di Kota Palu.

8. Estetika berpengaruh signifikan terhadap kepuasan konsumen membeli BB Cream Wardah di Kota Palu.

9. Kualitas yang dipersepsikan berpengaruh signifikan terhadap kepuasan konsumen membeli BB Cream Wardah di Kota Palu.

\section{Saran}

Berdasarkan kesimpulan yang telah diuraikan sebelumnya, maka saran-saran yang tepat menyangkut kegunaan penelitian ini dapat diuraikan sebagai berikut:

1. Kepada perusahaan yang menjual BB Cream Wardah di Kota Palu agar mempertahankan kualitas produk demi kepuasan konsumen dan lebih memperhatikan factor lain dalam kualitas produk selain dari faktor yang diteliti dalam penelitian ini.

2. Kepada peneliti selanjutnya disarankan untuk memasukkan variabel lain, selain yang digunakan dalam penelitian ini sehingga lebih dapat mengukur sebab-sebab yang mempengaruhi kepuasan konsumen BB Cream Wardahdi Kota Palu, selain itu juga diharapkan untuk menggunakan ukuran sampel yang lebih besar dari jumlah sampel yang digunakan pada penelitian ini sehingga keakuratan hasil penelitian akan terjamin.

\section{REFERENSI}

Ghozali.2011. Aplikasi Analisis Multivariate dengan Program SPSS. (Trans: Application of Multivariate Analysis using SPSS). Badan Penerbit UNDIP, ISBN 979.704.300.2. Semarang.

Kotler, Philip dan Kevin Lane Keller. 2009. Manajemen Pemasaran. Jilid 1dan 2 .Edisike 13.Diterjemahkan oleh Bob Sabran. Jakarta: Erlangga.

Lenzun et al, 2014. Pengaruh Kualitas Produk, Harga Dan Promosi Terhadap Kepuasan Pelanggan Kartu Prabayar Telkomsel. Jurnal EMBA, Vol 2, No 3.

Mulyono, Bayu Hadyanto. Yoestini. Nugraheni, Rini. Kamal, Mustofa. 2007. Analisis Pengaruh Kualitas Produk Dan Kualitas Layanan Terhadap Kepuasan Konsumen(Studi Kasus Pada Perumahan Puri Mediterania Semarang). Jurnal Studi Manajemen Dan Organisasi, Vol 4, No 2. 
JURNAL ILMU MANAJEMEN UNIVERSITAS TADULAKO

Vol. 4, No. 2, Mei 2019, p. 14 - 25

ISSN : 2443-3578 (On Line) / ISSN : 2443-1850 (Print)

Maulana Aan. Pengaruh Kualitas Produk Dan Nilai Pelanggan Terhadap Loyalitas Pelanggan Es Mahkota Di Kota Palu jurnal ilmu manajemen untad

Avita Haryanto Resty. 2013. Strategi promosi, kualitas produk, kualitas layanan terhadap kepuasan pelanggan pada restoran mcdonald's manado. Jurnal EMBA, Vol 1, No 4.

Sugiyono, 2014.Metode Penelitian administrasi. Bandung: Alfabeta.

Tjiptono, Fandy. 2008. Strategi Pemasaran. Edisi ketiga. Yogyakarta :Andi.

http://asihrahmawati1025.blogspot.co.id/2013/02/pt-paragon-tecnology-and-innovation_2575.html?=1

http://www.kosmetikz.com/harga-produk-wardah-kosmetik/

https://daniarfirdauzy.wordpress.com/2016/12/01/analisa-strategik-pt-paragon-technology-andinnovation-wardah-cosmeti 
JURNAL ILMU MANAJEMEN UNIVERSITAS TADULAKO

Vol. 5, No. 2, Mei 2019, p. $171-182$

ISSN : 2443-3578 (On Line) / ISSN : 2443-1850 (Print) 